\title{
Genetic basis of triatomine behavior: lessons from available insect genomes
}

\author{
Jose Manuel Latorre-Estivalis', Claudio Ricardo Lazzari², Alessandra Aparecida Guarneri', \\ Theo Mota ${ }^{3}$, Bonaventure Aman Omondi ${ }^{4}$, Marcelo Gustavo Lorenzo ${ }^{1 /+}$ \\ ${ }^{1}$ Centro de Pesquisas René Rachou-Fiocruz, Belo Horizonte, MG, Brasil \\ ${ }^{2}$ Institut de Recherche sur la Biologie de I'Insecte, Université François Rabelais de Tours, Tours, Indre et Loire, France \\ ${ }^{3}$ Departamento de Fisiologia e Biofísica, Instituto de Ciências Biológicas, Universidade Federal de Minas Gerais, Belo Horizonte, MG, Brasil \\ ${ }^{4}$ Chemical Ecology Unit, Department of Plant Protection Biology, Swedish University of Agricultural Sciences, Alnarp, Sweden
}

Triatomines have been important model organisms for behavioural research. Diverse reports about triatomine host search, pheromone communication in the sexual, shelter and alarm contexts, daily cycles of activity, refuge choice and behavioural plasticity have been published in the last two decades. In recent times, a variety of molecular genetics techniques has allowed researchers to investigate elaborate and complex questions about the genetic bases of the physiology of insects. This, together with the current characterisation of the genome sequence of Rhodnius prolixus allows the resurgence of this excellent insect physiology model in the omics era. In the present revision, we suggest that studying the molecular basis of behaviour and sensory ecology in triatomines will promote a deeper understanding of fundamental aspects of insect and, particularly, vector biology. This will allow uncovering unknown features of essential insect physiology questions for a hemimetabolous model organism, promoting more robust comparative studies of insect sensory function and cognition.

Key words: behaviour - sensory physiology - olfaction - genes - triatomines

Triatomine behaviour as a basis for functional genetics - Kissing-bugs have become an important model organism for neuroethological studies in the last two decades (Guerenstein \& Lazzari 2009, Manrique \& Lorenzo 2012, Lazzari et al. current issue). The range of topics covered includes host search mechanisms (Guerenstein \& Lazzari 2009), pheromone communication in contexts like mating (Manrique \& Lorenzo 2012), shelter recognition (Lorenzo \& Lazzari 1996) and predation risk (Ward 1981, Manrique et al. 2006), circadian rhythms and microclimatic preferences (Lazzari 1991, Roca \& Lazzari 1994, Lorenzo \& Lazzari 1999, Guarneri et al. 2002, 2003), state dependency (Bodin et al. 2009a, b) and diverse forms of learning (Vinauger et al. 2011a, b, 2012, 2013).

Triatomine host searching mechanisms include orientation to airstreams laden with $\mathrm{CO}_{2}$ and other host odours (Núñez 1982, Taneja \& Guerin 1995, Barrozo \& Lazzari 2004), exploitation of bird and mammal emission of infrared radiation (Lazzari \& Núñez 1989, Flores \& Lazzari 1996, Ferreira et al. 2007) and orientation to sources of water vapour (Barrozo et al. 2003). Furthermore, the intensity of these responses depends on modulatory fac-

doi: 10.1590/0074-0276130454

Financial support: INCTEM (573959/2008-0), FAPEMIG (APQ01359-11), PROEP-FIOCRUZ (401973/2012-3), CsF-CNPq (400091/2013-5), FIOCRUZ (visiting researcher fellowship programme) (550017/2012-7, to JMLE)

+Corresponding author: marcelo@cpqrr.fiocruz.br

Received 16 September 2013

Accepted 10 December 2013 tors such as the phase of the daily cycle (Barrozo et al. 2004, Bodin et al. 2008), bug nutritional status (Bodin et al. 2009a) and experience (Vinauger et al. 2011a, b).

Kissing bugs also communicate through pheromones in diverse behavioural contexts (Lazzari et al. current issue). Disturbed adult triatomines emit alarm pheromones to trigger avoidance of the emission spot by conspecifics (Ward 1981, Manrique et al. 2006) and this has been suggested to mediate the avoidance of predators (Manrique et al. 2006). A pheromone also mediates triatomine aggregation inside shelters (Schofield \& Patterson 1977, Figueiras et al. 1994, Lorenzo \& Lazzari 1996, Pires et al. 2002b). The use of shelters during daylight hours is fundamentally driven by their strong negative phototaxis (Reisenman et al. 1998) and at a later phase by an intense thigmotactic behaviour. In addition, these insects locate bug aggregations searching for shelters marked with triatomine faeces. Once inside refuges, a contact chemical signal present in their cuticule induces their arrestment (Figueiras et al. 2009). Finally, a sex pheromone is emitted by female adults to attract males (Manrique et al. 2006, Pontes et al. 2008, Vitta et al. 2009, MayConcha et al. 2013). Sexual signals also mediate male aggregation around mating pairs, apparently promoting polyandric reproduction in some bug species (Crespo \& Manrique 2007, Pontes \& Lorenzo 2012). Nevertheless, the latter seems not to be generalised in the subfamily Triatominae (Pires et al. 2004).

These insects seem to evaluate the adequacy of potential refuges by their physical properties (Lorenzo \& Lazzari 1999). Temperature and relative humidity range preferences apparently vary from species to species (Lazzari 1991, Roca \& Lazzari 1994, Guarneri et al. 2002, 2003, Pires et al. 2002a, Schilman \& Lazzari 2004). The level of 
illumination and light spectral qualities of their environments clearly affect their spatial choices and the intensity of these responses seems to depend on the phase of the daily cycle (Reisenman et al. 1998, 2002). Vision also plays an important role in locomotion, flight orientation and spatial recognition by triatomines (Lazzari \& Varjú 1990, Reisenman et al. 1998, 2000, Minoli \& Lazzari 2006, Reisenman \& Lazzari 2006, Insausti et al. 2013).

Triatomine behaviour is finely controlled by circadian clocks (Lazzari 1992, Barrozo et al. 2004, Guerenstein \& Lazzari 2009). In fact, activities are distributed within two precise temporal windows: one after dusk devoted to host search and another at dawn, dedicated to shelter location, egg-hatching and ecdysis (Lazzari et al. 2013). Each activity peak is under the control of a specific endogenous oscillator that establishes the proper timing (Lazzari 1992).

There is a clear state dependency in the motivation of these insects to search for hosts, shelters and mates. Host search is modulated by age, nutritional status and reproductive condition (Bodin et al. 2008, 2009a). Recently-fed insects and gravid females avoid host associated odours (Bodin et al. 2009a). The search for refuges also depends on the nutritional state and the phase of the diel cycle (Lorenzo \& Lazzari 1998). The search for reproductive mates and mating receptivity depend upon the age since the adult ecdysis and the nutritional state of the adult insects (Manrique \& Lazzari 1994, Vitta \& Lorenzo 2009).

The advent of next-generation sequencing (NGS), gene expression/regulation techniques and heterologous expression systems in the post-genomic era - Many insect genomes have been sequenced to date, forming a rich source of appropriate orthologues of behaviour controlling genes to initiate searches in the Rhodnius prolixus genome. Particularly, the genome of the pea aphid Acyrthosiphon pisum represents one of the best candidates for guiding BLAST searches due to their closer phylogenetic relation (The International Aphid Genomics Consortium 2010). This will be more relevant whenever a greater functional characterisation of this genome is made available. An assortment of gene sequencing, silencing, deletion and heterologous expression techniques have enabled more elaborate studies on the genetic bases of biological processes (Figure). Insect physiology benefited from this wealth of novel techniques and has shown impressive progress concomitant with the amazing potential of one particular insect model, Drosophila melanogaster (Table). In the last decades, it has been adopted as a main model for the study of the genetic and molecular bases of behaviour, being central to current neuroscience. The molecular mechanisms underlying circadian rhythms, plasticity and the formation of memories, sensory function and even, sexual behaviour have been studied in Drosophila (Table). Nevertheless, it presents limitations for neuroscience studies due its small size that restricts manipulation. For example, studies like those developed by VB Wigglesworth using $R$. prolixus as an insect model for the study of metamorphosis and neurosecretory function could only be performed thanks to an extremely practical model that allowed surgical procedures with minimal deleterious consequences. The present paper intends to propose $R$. prolixus as a new tool for the study of insect neuroscience due to these three characteristics: manipulation-friendly size, background as a classical insect physiology model and deep knowledge of diverse aspects of its behaviour. These facts, together with the recent characterisation of its genome sequence, will allow the resurgence of an excellent insect physiology model, as in Wigglesworth's time, but in the omics era. Next follows a series of aspects of triatomine behaviour, as well as related candidate genes uncovered for other insects, whose characterisation and study would be invaluable in $R$. prolixus and other relevant Chagas disease vectors.

The molecular basis of insect behaviour as a framework for studies on triatomines - Sensory ecology of host searching - Host location in triatomines is dependent on environmental and physiological conditions evaluated by their brain in order to regulate a proper expression of this behaviour. When properly motivated to feed, these insects

FUNCTIONAL GENETICS

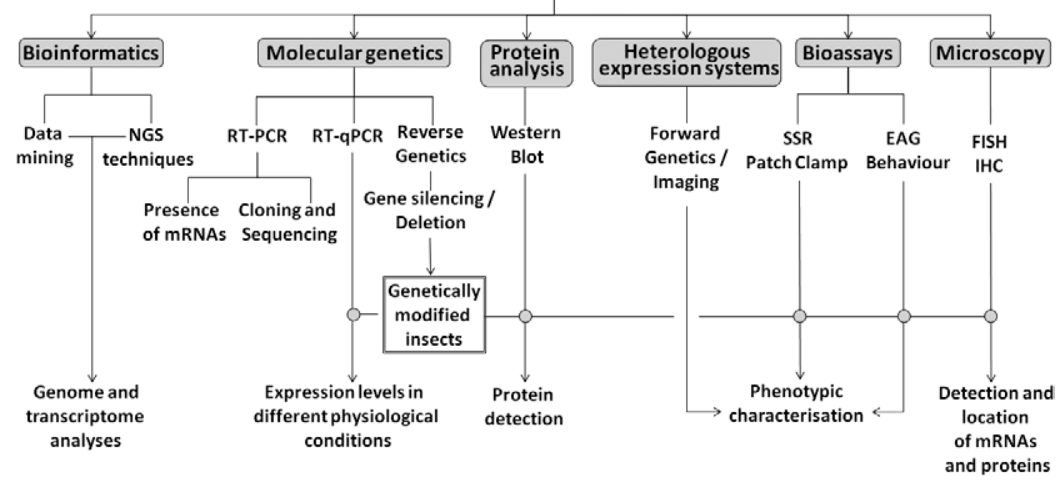

Workflow scheme for the study of functional genetics underlying triatomine behaviour. EAG: electroantennogram; FISH: fluorescence in situ hybridisation; IHC: immunohistochemistry; NGS: next-generation sequencing; qPCR: quantitative polymerase chain reaction; RT: reverse transcription; SSR: single sensillum recording. 


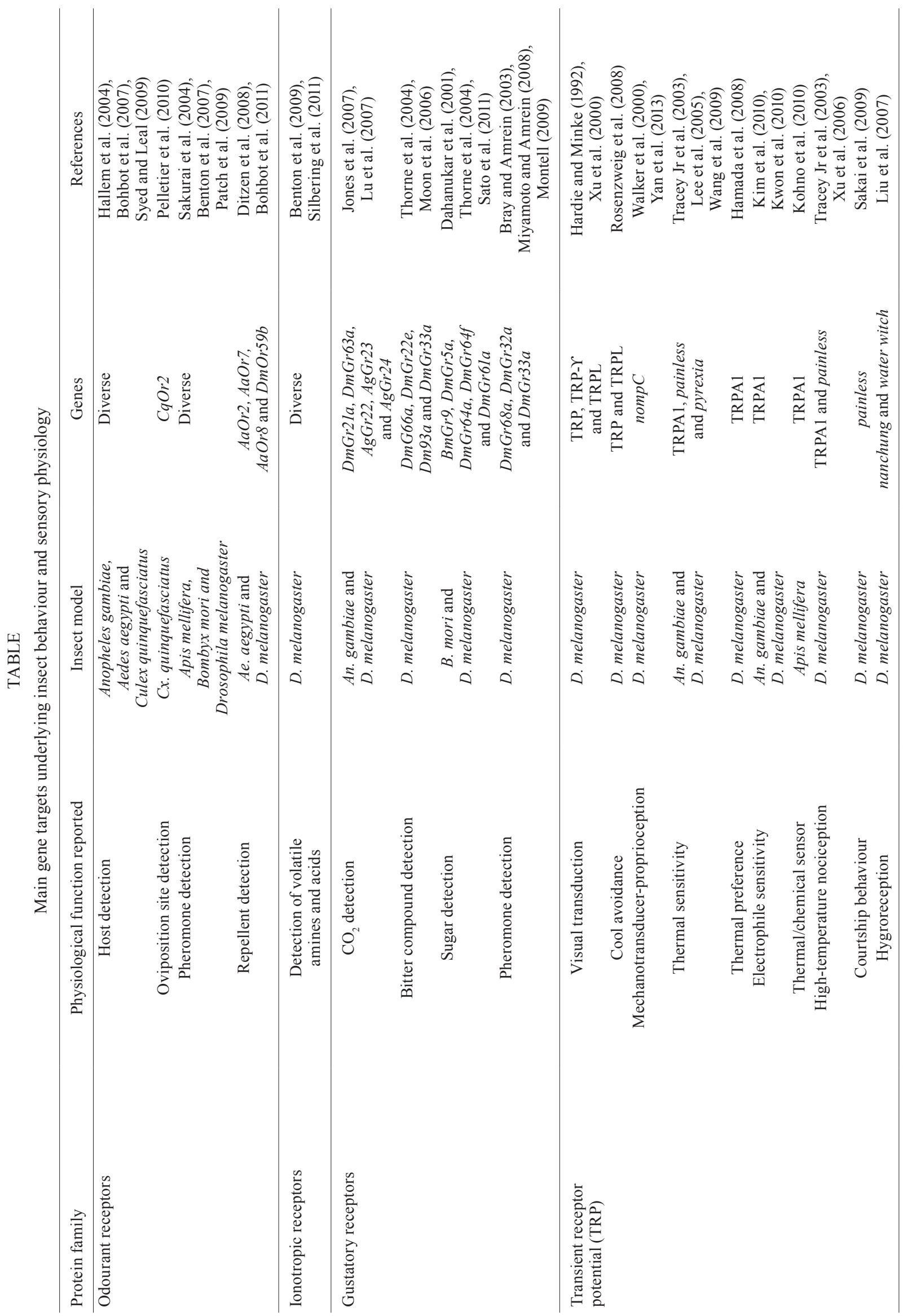




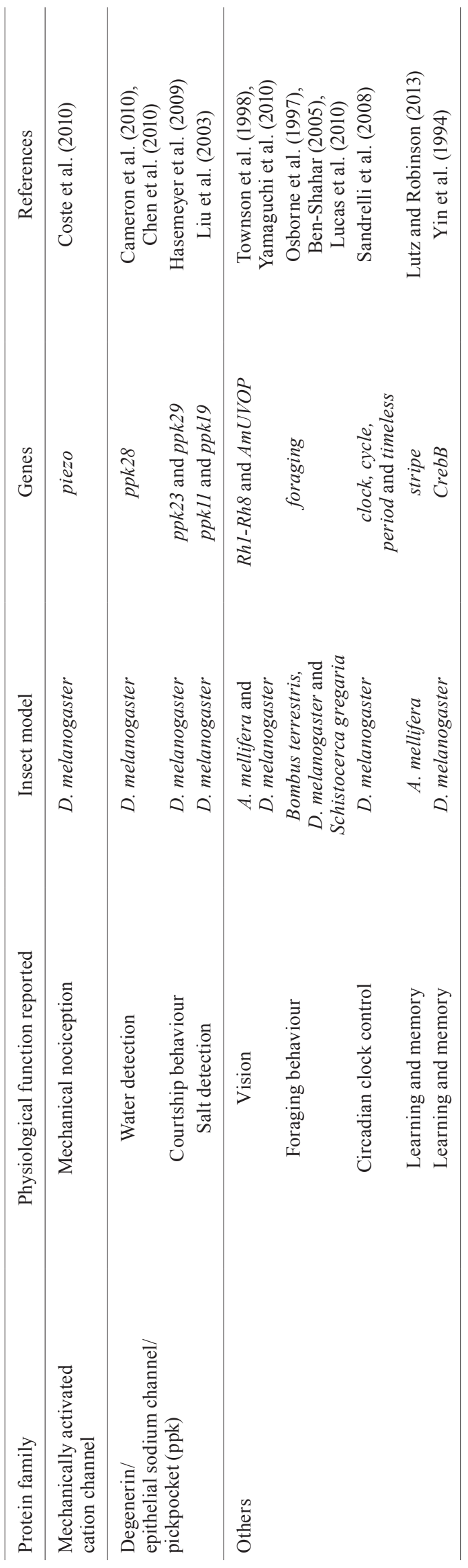

need to locate warm-blooded animals for a blood meal. As mentioned above, this task is performed detecting host signals through an array of sensory channels that include the detection of $\mathrm{CO}_{2}$, diverse odours, heat and water vapour. Once host detection is achieved, these insects approach the animal and finally need to find an appropriate biting site to pierce a blood vessel. All these behavioural steps depend on the detection of stimuli at sensory neurons in the periphery of their nervous system.

Chemoreceptor mediated host searching - $\mathrm{CO}_{2}$ is considered a long distance host cue promoting both the activation of resting triatomines and their orientation through odour modulated anaemotaxis (Barrozo \& Lazzari 2004). The physiological and molecular bases of detection of this host cue are unknown for triatomines, but relevant progress has been made to uncover a similar mechanism in two dipterans (Jones et al. 2007, Lu et al. 2007). According to these reports, both Drosophila and Anopheles gambiae detect $\mathrm{CO}_{2}$ with heterodimers composed of gustatory receptors (GRs) that are co-expressed in specific olfactory receptor neurons (ORNs). These receptors (DmGr21a and DmGr63a) are expressed in the antennae of D. melanogaster and the maxillary palps of An. gambiae (AgGr22, AgGr23 and AgGr24). These GRs belong to three ancient lineages of GRs also found in moths and beetles (Robertson \& Kent 2009). Surprisingly, these gene lineages have not been found in other arthropods like aphids, lice, honey bees, water fleas and black-legged ticks. Nevertheless, some of these arthropods are known to detect $\mathrm{CO}_{2}$, suggesting that they evolved a different molecular mechanism to detect this cue. The study of the molecular bases of $\mathrm{CO}_{2}$ detection by triatomines is therefore relevant and will rely on diverse bioassays already developed.

Host odours other than $\mathrm{CO}_{2}$ play a fundamental role in the orientation of triatomine bugs and their detection is probably mediated by proteins belonging to two different families: the odourant receptors (ORs) and the ionotropic receptors (IRs). In insects, ORs present seven transmembrane domains characteristic of all members of this protein family (Vosshall et al. 1999). In the ORNs expressing them, these receptors need to be co-expressed together with a phylogenetically conserved chaperon protein currently named "odourant receptor coreceptor-OrCo" for all insects (Larsson et al. 2004, Vosshall \& Hansson 2011). ORs are divergent proteins with low sequence identity between insect species and their roles cannot be predicted by sequence homology alone. Olfactory sensory neurons express different receptor genes, such that individual neurons are functionally distinct (Table). Numbers of ORs are extremely variable in insects, ranging from only 10 in the human louse to 265 in the flour beetle (TGSC et al. 2008, Kirkness et al. 2010).

A second family of insect ORs includes IRs, recently described in Drosophila, which present three transmembrane domains and constitute cation channels (Benton et al. 2009). These proteins have been suggested to mediate olfaction and taste in protostomes, an apparently ancient function for detecting chemical signals from the environment (Croset et al. 2010). IRs have been proposed to 
act as dimers or trimers of subunits co-expressed in the same neuron, which comprise individual odour-specific receptors and one or two broadly expressed coreceptors (Abuin et al. 2011). The suggested coreceptor units for IRs have thus been named IR25a, IR8a and IR76b. The ORNs expressing IRs are restricted to chemoreceptor hairs characterised by being double-walled, wall pore sensilla (e.g., grooved-pegs) and appear to have a relatively conserved role for detection of a restricted set of odourants in different insects (Pophof 1997, Diehl et al. 2003, Yao et al. 2005, Qiu et al. 2006). According to Silbering et al. (2011), odourant detection by IRs represents an insect olfactory subsystem that evolved in parallel to OR based olfaction. Numbers of IRs also show a relevant degree of variation ranging from 12 in the human body louse to 95 in Aedes aegypti (Croset et al. 2010).

The identification of receptor genes mediating host odour detection in the $R$. prolixus genome along with an analysis of olfactory-driven behaviour in these insects may enable researchers to understand the mechanisms linking host recognition and triatomine behaviour. These receptors and their ligands need to be characterised using a multidisciplinary approach including the study of gene expression, its physiological modulation and the electrophysiological properties of the ORNs expressing them (Figure). A deeper comprehension of the olfactory physiology underlying triatomine host detection would permit the design of antagonists to block these functions, both for OR and IR proteins involved.

Thermo and hygroreceptor mediated host searching Triatomines make use of their highly developed thermal sense to detect potential hosts. These bugs detect the heat emitted by warm-blooded animals in the form of infrared radiation (Lazzari \& Núñez 1989, Schmitz et al. 2000). The antennae of these insects house infrared detection organs (Lazzari \& Wicklein 1994, Flores \& Lazzari 1996) and are also critical for the bilateral integration of thermal information necessary to approach hosts (Flores \& Lazzari 1996). Triatomine thermoreceptor neurons have been poorly studied and information on their electrophysiological properties is very limited (Bernard 1974). The physiology of thermoreceptor neurons and their receptor proteins should be studied in these insects, which represent one of the most practical models to determine the molecular basis of heat perception in animals. Several genes belonging to the transient receptor potential A (TRPA) subfamily are known to mediate thermoreception in D. melanogaster, An. gambiae and Apis mellifera. The TRPA proteins belong to the TRP superfamily, which is composed of seven subfamilies of transmembrane protein channels with a relevant role in diverse sensory modalities including vision, taste, smell, thermo and mechanosensation (Table). The members of the TRPA subfamily are characterised by presence of six transmembrane domains and large numbers of ankyrin motifs in the N-terminal domain (Montell 2005). Orthologous sequences in the genome of $R$. prolixus need to be identified. Thermoreceptor genes with functional roles such as TRPA1, pyrexia and painless have been described in Drosophila (Tracey Jr et al. 2003, Lee et al. 2005, Wang et al. 2009).
Water vapour has been implicated as a host signal used by triatomines during their approach to blood-meal sources (Barrozo et al. 2003) and the molecular basis of its detection have been well studied in D. melanogaster (Liu et al. 2007). Briefly, vinegar flies detect air humidity levels by means of two different TRP proteins belonging to the TRPV subfamily, nanchung (involved in detecting dry air) and water witch (required to detect moist air). An evaluation of possible orthologues of these genes in the genome of $R$. prolixus would allow functional studies on their role in host location.

Host recognition and biting - After their final approach, triatomines need to recognise surface properties on the potential host in order to trigger biting responses properly. These can be reinforced by stimuli perceived through diverse sensory channels, but fundamentally through thermoreception and contact chemoreception. The first is mediated by antennal thermodetection structures recognising warm surfaces and even warmer blood vessels (Flores \& Lazzari 1996, Ferreira et al. 2007). The second can be mediated by proteins belonging to at least two different families, the GRs and pickpocket receptors (ppks). Insect GRs are membrane proteins generally dedicated to detect non-volatile substances (Table). These are G protein-coupled receptors presenting seven transmembrane domains that mediate the recognition of substances present on substrates and are expressed in the cilia of neurons housed inside contact chemoreceptor sensilla (Clyne et al. 2000). Pickpocket receptors belong to the Degenerin/epithelial sodium channel gene family and present two transmembrane helixes, two short intracellular domains and a large cysteine-rich extracellular loop (Ben-Shahar 2011). In Drosophila, ppk receptors have been related with the detection of water, e.g. $p p k 28$ (Cameron et al. 2010, Chen et al. 2010) and salt, e.g. ppk11 and ppk19 (Liu et al. 2003). Their presence in the genome of $R$. prolixus should be assessed and their potential role in host recognition in triatomines evaluated.

Pheromones: the molecular basis of chemical communication processes - As already mentioned, pheromones are used by triatomines to exchange information in diverse behavioural contexts. The substances composing them are most probably detected by triatomine ORs, IRs, GRs and ppks which still need to be characterised. Potential agents blocking their functions may become alternatives for triatomine control, which suggests that the identification of genes coding for these receptors would be extremely relevant to allow their manipulation. In the case of sex pheromone detection, any receptors showing exclusive expression in adults, males or female triatomines should be main research targets and may be identified through NGS techniques such as RNAseq (GrosseWilde et al. 2011, Pitts et al. 2011, Bengtsson et al. 2012).

Spatial and temporal orientation - Negative phototaxis is a common behavioural trait of most triatomine bug species (Lazzari et al. 1998, Reisenman et al. 1998, 2000, Reisenman \& Lazzari 2006). This behavioral feature induces avoidance of open areas during daylight hours (Lorenzo \& Lazzari 1996, Mota \& Lorenzo 2012), 
which is mediated both by their compound eyes and ocelli (Lazzari et al. 1998, Reisenman et al. 1998). The sensitivity of behavioural responses mediating negative phototaxis in these insects varies in a circadian manner (Reisenman et al. 1998) and the migration of screening pigments in both visual organs is also under the control of a circadian clock (Reisenman et al. 2002). In contrast to their robust negative phototaxis, light sources become attractive to triatomines when adults initiate flight in search for new habitats, food and mates (Noireau \& Dujardin 2001, Vazquez-Prokopec et al. 2004, Minoli \& Lazzari 2006).

Insect visual pigments, as those of vertebrates, are photoreceptors composed of an opsin protein and a lightsensitive chromophore derived from retinal (Terakita 2005). Since most organisms synthesise a single type of chromophore, the diversity of visual pigment absorption spectra essentially depends on the opsin structure. Thus, the spectral sensitivity of a given species is controlled by the type of opsins existing in its genome and expressed in the retina cells of its visual organs (Briscoe \& Chittka 2001). $R$. prolixus offers an excellent model to study the molecular basis of vision in nocturnal arthropods. Characterisation of its visual receptor genes would enable understanding their relation to behaviour.

Little is known about the mechanisms of photoreception and visual processing in triatomines. Some behavioural studies suggest the ability of these bugs to discriminate between distinct spectral properties of visual stimuli (Reisenman et al. 1998, 2000, Minoli \& Lazzari 2006, Reisenman \& Lazzari 2006), but it remains unclear whether triatomine vision relies on chromatic and/ or achromatic mechanisms (Briscoe \& Chittka 2001). True colour vision depends on subtractive interactions between at least two photoreceptor types (Menzel \& Backhaus 1991), but so far the number of photoreceptor types in triatomine visual organs has not been reported. The study of opsin gene expression in triatomines could be combined with behavioural and neurobiological approaches to provide insights into the visual processing mechanisms displayed by these insects (Figure).

The expression of the triatomine behaviours listed so far is under a strict control of circadian clocks (Lazzari et al. 2004). This affects host search activity, egg hatching, moulting, the expression of thermopreference and the use of shelters (Lazzari et al. 2004). The study of the molecular bases of circadian rhythms has been one of the most elaborate areas in insect physiology in the last decades (Sandrelli et al. 2008). A complex network of genes controlling the circadian expression of insect behaviour, including main roles like those of clock, cycle, timeless and period (Table), has been characterised in Drosophila (Sandrelli et al. 2008). It is probable that orthologues of these and other clock genes exist in $R$. prolixus and their identity should be determined through bioinformatic searches. Likewise, their expression cycling profiles should be clarified to allow experimental studies on their control of relevant biological features of triatomine biology such as oscillations in olfactory sensitivity.
Motivation: modulation and plasticity - The levels of expression of locomotor activity in triatomines seem extremely plastic, varying from almost null in immature insects to intense in starved individuals. This particular aspect of triatomine behaviour makes their physiology a cyclic process of long starvation intervals interspersed with short gaps of blood repletion that trigger a cascade of neuroendocrine events promoting moulting. This discrete separation allows clearly associating experimental manipulation to gene expression alterations, establishing cause-effect relations not easily attributable for Drosophila or other classic models that feed continuously. The underlying physiological processes regulating locomotor activity have not been studied in detail and these may involve mechanisms regulating gene expression. In the last decade, the study of a gene named foraging ( for), encoding a cGMP-dependent protein kinase, has allowed a better comprehension of the genetic basis of locomotion in several insects (Reaume \& Sokolowski 2011). For example, individuals showing two distinct profiles of locomotor activity controlled by different alleles of the for gene, called rovers and sitters, exist in D. melanogaster (Osborne et al. 1997). For locusts, changes in the expression levels of this gene are associated with behavioural shifts characteristically triggered at high population densities (Lucas et al. 2010). In addition, variations in the expression of the for gene have been indicated to promote nurse honey bees to become foragers (Ben-Shahar 2005). The existence, function and regulation of this gene in the $R$. prolixus genome and its potential relation to the ample regulation of locomotor activity in triatomines deserve to be explored.

Brain production of diverse neuropeptides has been described in R. prolixus and their roles have been related to the control of bug physiology (Ons et al. 2009). Nevertheless, their impact on triatomine behaviour has not been analysed and their potential on the modulation of behaviour needs to be addressed. Many aspects of triatomine behaviour have been shown to be extremely plastic. Therefore, the study of the genetic and molecular bases of behaviour modulation in triatomines is necessary.

In recent years, several reports have shown that $R$. prolixus is capable of diverse forms of learning (Vinauger et al. 2011a, b, 2012, 2013, Minoli et al. 2013). These include simple habituation (Vinauger et al. 2013), associative learning with positive or aversive rewards (Vinauger et al. 2011a, b) and operant conditioning (Vinauger et al. 2013). All these facts indicate that this species might represent a friendly model to study molecular aspects of learning. Memory related genes, such as $C r e b B$ (Yin et al. 1994) or stripe (Lutz \& Robinson 2013) have already been described in other insects and their characterisation in triatomines would allow a deeper understanding of behavioural plasticity.

Behaviour modulation due to parasite infection is another relevant issue not properly evaluated for triatomines. Parasite-host associations are unapparent elements in an ecological community and affect competition relations intra and inter species, the distribution and abundance of species and even community composition 
(Horwitz \& Wilcox 2005). In this way hosts cannot be considered alone, as their relation with the environment and conspecifics necessarily includes their natural parasites. The ability of parasites to manipulate host phenotypes facilitating transmission is an important and well known paradigm in the study of the evolutionary biology of host-pathogen interactions (Thomas et al. 2005, Moore 2013). Changes in vector behaviour have been reported in different systems (Molyneux \& Jefferies 1986, Schaub 1989, 1992, Killick-Kendrick \& Molyneux 1990, Alekseev 1991, Hurd 2003, Lefevre \& Thomas 2008). Generally, these alterations affect feeding behaviour, fundamentally when parasites are transmitted by vector bites, as in African trypanosome infected tsetse flies (Jenni et al. 1980), Leishmania-infected sandflies (Beach et al. 1985 ) and Plasmodium-infected mosquitoes (Ribeiro et al. 1985, Rossignol et al. 1986, Koella et al. 1998). R. prolixus has its feeding behaviour affected when infected by Trypanosoma rangeli (Garcia et al. 1994). Authors suggest that this parasite interferes the synthesis of antihemostatic molecules during salivary gland infection, but Paim et al. (2013) showed an unspecific reduction of stored proteins in the salivary glands in the presence of T. rangeli. Other behavioural effects on vectors, such as alterations in locomotory activity in Ae. aegypti infected by dengue virus (Lima-Camara et al. 2011) and changes in foraging and defecation in Mepraia spinolai infected by Trypanosoma cruzi (Botto-Mahan et al. 2006) have been eventually reported, but many aspects of infected vector behaviour are still unstudied.

In spite of the significant advances described here for triatomine behaviour studies, little is known about whether trypanosome infection affects bug behaviour. The few studies concerning behavioural modifications in triatomines infected by trypanosomes suggest that such alterations may occur (Garcia et al. 1994, BottoMahan et al. 2006). Triatomines host several parasite species, such as $T$. cruzi, the causative agent of Chagas disease and T. rangeli. Alterations in triatomine behaviour caused by these parasites could affect their distribution or even increase parasite transmission rates. In case trypanosomes are capable of inducing changes in triatomine behaviour, the molecular mechanisms triggering this would need to be characterised.

The study of the molecular basis of behaviour in $R$. prolixus would allow a better understanding of fundamental features of vector biology. Besides, it would enable accessing relevant aspects of insect physiology mostly unknown for models other than classic holometabolous insects, like dipterans and moths. This would encourage comparative approaches to study insect sensory function, as well as cognition, at the molecular, cellular and organism level.

\section{REFERENCES}

Abuin L, Bargeton B, Ulbrich M, Isacoff E, Kellenberger S, Benton R 2011. Functional architecture of olfactory ionotropic glutamate receptors. Neuron 69: 44-60.

Alekseev AN 1991. Group and individual behaviour of infected and noninfected arthropods - vectors of diseases 2, Zoological Institute, St Petersburg, 15 pp.
Barrozo RB, Lazzari CR 2004. The response of the blood-sucking bug Triatoma infestans to carbon dioxide and other host odours. Chem Senses 29: 319-329.

Barrozo RB, Manrique G, Lazzari CR 2003. The role of water vapour in the orientation behaviour of the blood-sucking bug Triatoma infestans (Hemiptera, Reduviidae). J Insect Physiol 49: 315-321.

Barrozo RB, Minoli SA, Lazzari CR 2004. Circadian rhythm of behavioural responsiveness to carbon dioxide in the blood-sucking bug Triatoma infestans (Heteroptera: Reduviidae). J Insect Physiol 50: 249-254.

Beach R, Kiilu G, Leeuwenburg J 1985. Modification of sand fly biting behavior by Leishmania leads to increased parasite transmission. Am J Trop Med Hyg 34: 278-282.

Bengtsson JM, Trona F, Montagné N, Anfora G, Ignell R, Witzgall P, Jacquin-Joly E 2012. Putative chemosensory receptors of the codling moth, Cydia pomonella, identified by antennal transcriptome analysis. PLoS ONE 7: e31620.

Ben-Shahar Y 2005. The foraging gene, behavioral plasticity and honeybee division of labor. J Comp Physiol A Neuroethol Sens Neural Behav Physiol 191: 987-994.

Ben-Shahar Y 2011. Sensory functions for degenerin/epithelial sodium channels (DEG/ENaC). Adv Genet 76: 1-26.

Benton R, Vannice K, Gomez-Diaz C, Vosshall LB 2009. Variant ionotropic glutamate receptors as chemosensory receptors in Drosophila. Cell 136: 149-162.

Benton R, Vannice K, Vosshall LB 2007. An essential role for a CD36-related receptor in pheromone detection in Drosophila. Nature 450: 289-293.

Bernard J 1974. Étude électrophysiologique de récepteurs impliqués dans l'orientation vers l'hôte et dans l'acte hématophage chez un Hémiptère, Triatoma infestans, PhD Thesis, Université de Rennes, Rennes, 286 pp.

Bodin A, Barrozo RB, Couton L, Lazzari CR 2008. Temporal modulation and adaptive control of the behavioural response to odours in Rhodnius prolixus. J Insect Physiol 54: 1343-1348.

Bodin A, Vinauger C, Lazzari CR 2009a. Behavioural and physiological state dependency of host seeking in the blood-sucking insect Rhodnius prolixus. J Exp Biol 212: 2386-2393.

Bodin A, Vinauger C, Lazzari CR 2009b. State-dependency of hostseeking in Rhodnius prolixus: the post-ecdysis time. $J$ Insect Physiol 55: 574-579.

Bohbot J, Fu L, Le T, Chauhan K, Cantrell C, Dickens J 2011. Multiple activities of insect repellents on odorant receptors in mosquitoes. Med Vet Entomol 25: 436-444.

Bohbot J, Pitts R, Kwon HW, Rützler M, Robertson H, Zwiebel LJ 2007. Molecular characterization of the Aedes aegypti odorant receptor gene family. Insect Mol Biol 16: 525-537.

Botto-Mahan C, Cattan PE, Medel R 2006. Chagas disease parasite induces behavioural changes in the kissing bug Mepraia spinolai. Acta Trop 98: 219-223.

Bray S, Amrein H 2003. A putative Drosophila pheromone receptor expressed in male-specific taste neurons is required for efficient courtship. Neuron 39: 1019-1029.

Briscoe AD, Chittka L 2001. The evolution of color vision in insects. Annu Rev Entomol 46: 471-510.

Cameron P, Hiroi M, Ngai J, Scott K 2010. The molecular basis for water taste in Drosophila. Nature 465: 91-95.

Chen Z, Wang Q, Wang Z 2010. The amiloride-sensitive epithelial $\mathrm{Na}^{+}$channel ppk28 is essential for Drosophila gustatory water reception. J Neurosci 30: 6247-6252. 
Clyne P, Warr C, Carlson JR 2000. Candidate taste receptors in Drosophila. Science 287: 1830-1834.

Coste B, Mathur J, Schmidt M, Earley T, Ranade S, Petrus M, Dubin A, Patapoutian A 2010. Piezo1 and Piezo2 are essential components of distinct mechanically activated cation channels. Science 330: $55-60$.

Crespo J, Manrique G 2007. Mating behavior of the hematophagous bug Triatoma infestans: role of Brindley's and metasternal glands. J Insect Physiol 53: 708-714.

Croset V, Rytz R, Cummins S, Budd A, Brawand D, Kaessmann H, Gibson T, Benton R 2010. Ancient protostome origin of chemosensory ionotropic glutamate receptors and the evolution of insect taste and olfaction. PLoS Genet 6: e1001064.

Dahanukar A, Foster K, van der Goes van Naters WM, Carlson JR 2001. A Gr receptor is required for response to the sugar trehalose in taste neurons of Drosophila. Nat Neurosci 4: 1182-1186.

Diehl P, Vlimant M, Guerenstein PG, Guerin PM 2003. Ultrastructure and receptor cell responses of the antennal grooved peg sensilla of Triatoma infestans (Hemiptera: Reduviidae). Arthropod Struct Dev 31: 271-285.

Ditzen M, Pellegrino M, Vosshall LB 2008. Insect odorant receptors are molecular targets of the insect repellent DEET. Science 319: 1838-1842.

Ferreira RA, Lazzari CR, Lorenzo MG, Pereira MH 2007. Do haematophagous bugs assess skin surface temperature to detect blood vessels? PLOS ONE 2: e932.

Figueiras AL, Girotti JR, Mijailovsky SJ, Juárez MP 2009. Epicuticular lipids induce aggregation in Chagas disease vectors. Parasit Vectors 2: 8 .

Figueiras ANL, Kenigsten A, Lazzari CR 1994. Aggregation in the haematophagous bug Triatoma infestans: chemical signals and temporal pattern. J Insect Physiol 40: 311-316.

Figueiras ANL, Lazzari CR 1998a. Aggregation behaviour and interspecific responses in three species of Triatominae. Mem Inst Oswaldo Cruz 93: 133-137.

Figueiras ANL, Lazzari CR 1998b. Aggregation in the haematophagous bug Triatoma infestans: a novel assembling factor. Physiol Entomol 23: 33-37.

Flores GB, Lazzari CR 1996. The role of the antennae in Triatoma infestans: orientation towards thermal sources. J Insect Physiol 42: 433-440.

Garcia E, Mello C, Azambuja P, Ribeiro J 1994. Rhodnius prolixus: salivary antihemostatic components decrease with Trypanosoma rangeli infection. Exp Parasitol 78: 287-293.

Grosse-Wilde E, Kuebler LS, Bucks S, Vogel H, Wicher D, Hansson BS 2011. Antennal transcriptome of Manduca sexta. Proc Natl Acad Sci USA 108: 7449-7454.

Guarneri AA, Lazzari CR, Diotaiuti L, Lorenzo MG 2002. The effect of relative humidity on the behaviour and development of Triatoma brasiliensis. Physiol Entomol 27: 142-147.

Guarneri AA, Lazzari CR, Xavier AAP, Diotaiuti L, Lorenzo MG 2003. The effect of temperature on the behaviour and development of Triatoma brasiliensis. Physiol Entomol 28: 185-191.

Guerenstein PG, Lazzari CR 2009. Host-seeking: how triatomines acquire and make use of information to find blood. Acta Trop 110: $148-158$.

Hallem EA, Fox AN, Zwiebel LJ, Carlson JR 2004. Olfaction: mosquito receptor for human-sweat odorant. Nature 427: 212-213.
Hamada FN, Rosenzweig M, Kang K, Pulver SR, Ghezzi A, Jegla TJ, Garrity PA 2008. An internal thermal sensor controlling temperature preference in Drosophila. Nature 454: 217-220.

Hardie RC, Minke B 1992. The trp gene is essential for a light-activated $\mathrm{Ca}_{2+}$ channel in Drosophila photoreceptors. Neuron 8: 643-651.

Hasemeyer M, Yapici N, Heberlein U, Dickson BJ 2009. Sensory neurons in the Drosophila genital tract regulate female reproductive behavior. Neuron 61: 511-518.

Horwitz P, Wilcox BA 2005. Parasites, ecosystems and sustainability: an ecological and complex systems perspective. Int J Parasitol 35: 725-732.

Hurd H 2003. Manipulation of medically important insect vectors by their parasites. Annu Rev Entomol 48: 141-161.

Insausti TC, Le Gall M, Lazzari CR 2013. Oxidative stress, photodamage and the role of screening pigments in insect eyes. $J$ Exp Biol 216: 3200-3207.

Jenni L, Molyneux D, Livesey J, Galun R 1980. Feeding behaviour of tsetse flies infected with salivarian trypanosomes. Nature 283: 383-385.

Jones W, Cayirlioglu P, Kadow I, Vosshall LB 2007. Two chemosensory receptors together mediate carbon dioxide detection in Drosophila. Nature 445: 86-90.

Killick-Kendrick R, Molyneux DH 1990. Interrupted feeding of vectors. Parasitol Today 6: 188-189.

Kim SH, Lee Y, Akitake B, Woodward OM, Guggino WB, Montell C 2010. Drosophila TRPA1 channel mediates chemical avoidance in gustatory receptor neurons. Proc Natl Acad Sci USA 107: 8440-8445.

Kirkness E, Haas B, Sun W, Braig H, Perotti M, Clark J, Lee S, Robertson HM, Kennedy R, Elhaik E, Gerlach D, Kriventseva E, Elsik C, Graur D, Hill C, Veenstra J, Walenz B, Tubío J, Ribeiro J, Rozas J, Johnston J, Reese J, Popadic A, Tojo M, Raoult D, Reed D, Tomoyasu Y, Kraus E, Krause E, Mittapalli O, Margam V, Li H-M, Meyer J, Johnson R, Romero-Severson J, Vanzee J, Alvarez-Ponce D, Vieira F, Aguadé M, Guirao-Rico S, Anzola J, Yoon K, Strycharz J, Unger M, Christley S, Lobo N, Seufferheld M, Wang N, Dasch G, Struchiner C, Madey G, Hannick L, Bidwell S, Joardar V, Caler E, Shao R, Barker S, Cameron S, Bruggner R, Regier A, Johnson J, Viswanathan L, Utterback T, Sutton G, Lawson D, Waterhouse R, Venter J, Strausberg R, Berenbaum M, Collins F, Zdobnov E, Pittendrigh B 2010. Genome sequences of the human body louse and its primary endosymbiont provide insights into the permanent parasitic lifestyle. Proc Natl Acad Sci USA 107: 12168-12173.

Koella JC, Sörensen FL, Anderson R 1998. The malaria parasite, Plasmodium falciparum, increases the frequency of multiple feeding of its mosquito vector, Anopheles gambiae. Proc Biol Sci 265: 763-768.

Kohno K, Sokabe T, Tominaga M, Kadowaki T 2010. Honey bee thermal/chemical sensor, AmHsTRPA, reveals neofunctionalization and loss of transient receptor potential channel genes. J Neurosci 30: $12219-12229$

Kwon Y, Kim SH, Ronderos DS, Lee Y, Akitake B, Woodward OM, Guggino WB, Smith DP, Montell C 2010. Drosophila TRPA1 channel is required to avoid the naturally occurring insect repellent citronellal. Curr Biol 20: 1672-1678.

Larsson MC, Domingos AI, Jones WD, Chiappe ME, Amrein H, Vosshall LB 2004. Or83b encodes a broadly expressed odorant receptor essential for Drosophila olfaction. Neuron 43: 703-714.

Lazzari CR 1991. Temperature preference in Triatotna infestans (Hemiptera: Reduviidae). Bull Ent Res 81: 273-276. 
Lazzari CR 1992. Circadian organization of locomotion activity in the haematophagous bug Triatoma infestans. J Insect Physiol 38: 895-903.

Lazzari CR, Minoli SA, Barrozo RB 2004. Chemical ecology of insect vectors: the neglected temporal dimension. Trends Parasitol 20: $506-507$

Lazzari CR, Núñez JA 1989. The response to radiant heat and the estimantion of the temperature of distant sources in Triatoma infestans. J Insect Physiol 35: 525-529.

Lazzari CR, Pereira MH, Lorenzo MG 2013. Behavioural biology of Chagas disease vectors. Mem Inst Oswaldo Cruz 108: 34-47.

Lazzari CR, Reiseman CE, Insausti TC 1998. The role of the ocelli in the phototactic behaviour of the haematophagous bug Triatoma infestans. J Insect Physiol 44: 1159-1162.

Lazzari CR, Varjú D 1990. Visual lateral fixation and tracking in the haematophagous bug Triatoma infestans. J Comp Physiol A 167: 527-531.

Lazzari CR, Wicklein M 1994. The cave-like sense organ in the antennae of Triatominae bugs. Mem Inst Oswaldo Cruz 89: 643-648.

Lee Y, Lee Y, Lee J, Bang S, Hyun S, Kang J, Hong S-T, Bae E, Kaang B-K, Kim J 2005. Pyrexia is a new thermal transient receptor potential channel endowing tolerance to high temperatures in Drosophila melanogaster. Nat Genet 37: 305-310.

Lefevre T, Thomas F 2008. Behind the scene, something else is pulling the strings: Emphasizing parasitic manipulation in vectorborne diseases. Infect Genet Evol 8: 504-519.

Lima-Camara TN, Bruno RV, Luz PM, Castro MG, Lourenço-deOliveira R, Sorgine MH, Peixoto AA 2011. Dengue infection increases the locomotor activity of Aedes aegypti females. PLoS ONE 6: e17690.

Liu L, Leonard A, Motto D, Feller M, Price M, Johnson W, Welsh M 2003. Contribution of Drosophila DEG/ENaC genes to salt taste. Neuron 39: 133-146.

Liu L, Li Y, Wang R, Yin C, Dong Q, Hing H, Kim C, Welsh M 2007. Drosophila hygrosensation requires the TRP channels water witch and nanchung. Nature 450: 294-298.

Lorenzo MG, Lazzari CR 1996. The spatial pattern of defaecation in Triatoma infestans and the role of faeces as a chemical mark of the refuge. J Insect Physiol 42: 903-907.

Lorenzo MG, Lazzari CR 1998. Activity pattern in relation to refuge exploitation and feeding in Triatoma infestans (Hemiptera: Reduviidae). Acta Trop 70: 163-170.

Lorenzo MG, Lazzari CR 1999. Temperature and relative humidity affect the selection of shelters by Triatoma infestans, vector of Chagas disease. Acta Trop 72: 241-249.

Lu T, Qiu Y, Wang G, Kwon J, Rutzler M, Kwon H-W, Pitts R, van Loon J, Takken W, Carlson JR, Zwiebel LJ 2007. Odor coding in the maxillary palp of the malaria vector mosquito Anopheles gambiae. Curr Biol 17: 1533-1544.

Lucas C, Kornfein R, Chakaborty-Chatterjee M, Schonfeld J, Geva N, Sokolowski MB, Ayali A 2010. The locust foraging gene. Arch Insect Biochem Physiol 74: 52-66.

Lutz CC, Robinson GE 2013. Activity-dependent gene expression in honey bee mushroom bodies in response to orientation flight. $J$ Exp Biol 216: 2031-2038.

Manrique G, Lazzari CR 1994. Sexual behaviour and stridulation during mating in Triatoma infestans (Hemiptera: Reduviidae). Mem Inst Oswaldo Cruz 89: 629-633.

Manrique G, Lorenzo MG 2012. The sexual behaviour of Chagas disease vectors: chemical signals mediating communication between male and female Triatomine Bugs. Psyche (Camb Mass) 2012: 8 pp.

Manrique G, Vitta AC, Ferreira RA, Zani CL, Unelius CR, Lazzari CR, Diotaiuti L, Lorenzo MG 2006. Chemical communication in Chagas disease vectors. Source, identity and potential function of volatiles released by the metasternal and Brindley's glands of Triatoma infestans adults. $J$ Chem Ecol 32: 2035-2052.

May-Concha I, Rojas JC, Cruz-López L, Millar JG, Ramsey JM 2013. Volatile compounds emitted by Triatoma dimidiata, a vector of Chagas disease: chemical analysis and behavioural evaluation. Med Vet Entomol 27: 165-174.

Menzel R, Backhaus W 1991. Colour vision in insects. In P Gouras (ed.), Vision and visual dysfunction, The perception of color, Vol. 6, Macmillan, London, p. 262-293.

Minoli SA, Lazzari CR 2006. Take-off activity and orientation of triatomines (Heteroptera: Reduviidae) in relation to the presence of artificial lights. Acta Trop 97: 324-330.

Minoli SA, Palottini F, Manrique G 2013. The main component of an alarm pheromone of kissing bugs plays multiple roles in the cognitive modulation of the escape response. Front Behav Neurosci 7: 77 .

Miyamoto T, Amrein H 2008. Suppression of male courtship by a Drosophila pheromone receptor. Nat Neurosci 11: 874-876.

Molyneux D, Jefferies D 1986. Feeding behaviour of pathogen-infected vectors. Parasitology 92: 721-736.

Montell C 2005. The TRP superfamily of cation channels. Sci STKE 2005: re3.

Montell C 2009. A taste of the Drosophila gustatory receptors. Curr Opin Neurobiol 19: 345-353.

Moon SJ, Kottgen M, Jiao Y, Xu H, Montell C 2006. A taste receptor required for the caffeine response in vivo. Curr Biol 16: 1812-1817.

Moore J 2013. An overview of parasite-induced behavioral alterations and some lessons from bats. J Exp Biol 216: 11-17.

Mota T, Lorenzo MG 2012. Lack of segregation between two species of Chagas disease vectors. Am J Trop Med Hyg 87: 109-116.

Noireau F, Dujardin J-P 2001. Flight and nutritional status of sylvatic Triatoma sordida and Triatoma guasayana. Mem Inst Oswaldo Cruz 96: 385-389.

Núñez JA 1982. Food source orientation and activity in Rhodnius prolixus Stål (Hemiptera: Reduviidae). Bull Ent Res 72: 253-262.

Ons S, Richter F, Urlaub H, Pomar RR 2009. The neuropeptidome of Rhodnius prolixus brain. Proteomics 9: 788-792.

Osborne KA, Robichon A, Burgess E, Butland S, Shaw RA, Coulthard A, Pereira HS, Greenspan RJ, Sokolowski MB 1997. Natural behavior polymorphism due to a cGMP-dependent protein kinase of Drosophila. Science 277: 834-836.

Paim RM, Pereira MH, Araújo RN, Gontijo NF, Guarneri AA 2013. The interaction between Trypanosoma rangeli and the nitrophorins in the salivary glands of the triatomine Rhodnius prolixus (Hemiptera; Reduviidae). Insect Biochem Mol Biol 43: 229-236.

Patch HM, Velarde RA, Walden KK, Robertson HM 2009. A candidate pheromone receptor and two odorant receptors of the hawkmoth Manduca sexta. Chem Senses 34: 305-316.

Pelletier J, Hughes D, Luetje C, Leal W 2010. An odorant receptor from the southern house mosquito Culex pipiens quinquefasciatus sensitive to oviposition attractants. PLoS ONE 5: e10090. 
Pires HHR, Lazzari CR, Schilman PE, Diotaiuti L, Lorenzo MG 2002a. Dynamics of thermopreference in the Chagas disease vector Panstrongylus megistus (Hemiptera: Reduviidae). J Med Entomol 39: 716-719.

Pires HHR, Lorenzo MG, Diotaiuti L, Lazzari CR, Figueiras AL 2002b. Aggregation behaviour in Panstrongylus megistus and Triatoma infestans: inter and intraspecific responses. Acta Trop 81: 47-52.

Pires HHR, Lorenzo MG, Lazzari CR, Diotaiuti L, Manrique G 2004. The sexual behaviour of Panstrongylus megistus (Hemiptera: Reduviidae): an experimental study. Mem Inst Oswaldo Cruz 99: 295-300.

Pitts RJ, Rinker DC, Jones PL, Rokas A, Zwiebel LJ 2011. Transcriptome profiling of chemosensory appendages in the malaria vector Anopheles gambiae reveals tissue and sex-specific signatures of odor coding. BMC Genomics 12: 271.

Pontes G, Bohman B, Unelius C, Lorenzo MG 2008. Metasternal gland volatiles and sexual communication in the triatomine bug, Rhodnius prolixus. J Chem Ecol 34: 450-457.

Pontes G, Lorenzo MG 2012. Female metasternal gland odours mediate male aggregation in Rhodnius prolixus, a triatomid bug. Med Vet Entomol 26: 33-36.

Pophof B 1997. Olfactory responses recorded from sensilla coeloconica of the silkmoth Bombyx mori. Physiol Entomol 22: 239-248.

Qiu YT, van Loon JJ, Takken W, Meijerink J, Smid HM 2006. Olfactory coding in antennal neurons of the malaria mosquito, Anopheles gambiae. Chem Senses 31: 845-863.

Reaume CJ, Sokolowski MB 2011. Conservation of gene function in behaviour. Phil Trans R Soc B 366: 2100-2110.

Reisenman CE, Figueiras ANL, Giurfa M, Lazzari CR 2000. Interaction of visual and olfactory cues in the aggregation behaviour of the haematophagous bug Triatoma infestans. J Comp Physiol A 186: 961-968.

Reisenman CE, Insausti TC, Lazzari CR 2002. Light-induced and circadian changes in the compound eye of the haematophagous bug Triatoma infestans (Hemiptera: Reduviidae). J Exp Biol 205: 201-210.

Reisenman CE, Lazzari CR 2006. Spectral sensitivity of the photonegative reaction of the blood-sucking bug Triatoma infestans (Heteroptera: Reduviidae). J Comp Physiol A Neuroethol Sens Neural Behav Physiol 192: 39-44.

Reisenman CE, Lazzari CR, Giurfa M 1998. Circadian control of photonegative sensitivity in the haematophagous bug Triatoma infestans. J Comp Physiol A 183: 533-541.

Ribeiro J, Rossignol P, Spielman A 1985. Aedes aegypti: model for blood finding strategy and prediction of parasite manipulation. Exp Parasitol 60: 118-132.

Robertson HM, Kent L 2009. Evolution of the gene lineage encoding the carbon dioxide receptor in insects. J Insect Sci 9: 19.

Roca MJ, Lazzari CR 1994. Effects of relative humidity on the haematophagous bug Triatoma infestans: hygropreference and eclosion success. J Insect Physiol 40: 901-907.

Rosenzweig M, Kang K, Garrity P 2008. Distinct TRP channels are required for warm and cool avoidance in Drosophila melanogaster. Proc Natl Acad Sci USA 105: 14668-14673.

Rossignol P, Ribeiro J, Spielman A 1986. Increased biting rate and reduced fertility in sporozoite-infected mosquitoes. Am J Trop Med Hyg 35: 277-279.

Sakai T, Kasuya J, Kitamoto T, Aigaki T 2009. The Drosophila TRPA channel, painless, regulates sexual receptivity in virgin females. Genes Brain Behav 8: 546-557.
Sakurai T, Nakagawa T, Mitsuno H, Mori H, Endo Y, Tanoue S, Yasukochi Y, Touhara K, Nishioka T 2004. Identification and functional characterization of a sex pheromone receptor in the silkmoth Bombyx mori. Proc Natl Acad Sci USA 101: 16653-16658.

Sandrelli F, Costa R, Kyriacou CP, Rosato E 2008. Comparative analysis of circadian clock genes in insects. Insect Mol Biol 17: 447-463.

Sato K, Tanaka K, Touhara K 2011. Sugar-regulated cation channel formed by an insect gustatory receptor. Proc Natl Acad Sci USA 108: 11680-11685.

Schaub G 1989. Trypanosoma cruzi: quantitative studies of development of two strains in small intestine and rectum of the vector Triatoma infestans. Exp Parasitol 68: 260-273.

Schaub GA 1992. The effects of trypanosomatids on insects. $A d v$ Parasitol 31: 255-319.

Schilman PE, Lazzari CR 2004. Temperature preference in Rhodnius prolixus, effects and possible consequences. Acta Trop 90: 115-122.

Schmitz H, Trenner S, Hofmann MH, Bleckmann H 2000. The ability of Rhodnius prolixus (Hemiptera, Reduviidae) to approach a thermal source solely by its infrared radiation. J Insect Physiol 46: 745-751.

Schofield G, Patterson J 1977. Assembly pheromone of Triatoma infestans and Rhodnius prolixus nymphs (Hemiptera: Reduviidae). J Med Entomol 13: 727-734.

Silbering A, Rytz R, Grosjean Y, Abuin L, Ramdya P, Jefferis G, Benton R 2011. Complementary function and integrated wiring of the evolutionarily distinct Drosophila olfactory subsystems. $J$ Neurosci 31: 13357-13375.

Syed Z, Leal W 2009. Acute olfactory response of Culex mosquitoes to a human - and bird-derived attractant. Proc Natl Acad Sci USA 106: $18803-18808$.

Taneja J, Guerin PM 1995. Oriented responses of the triatomine bugs Rhodnius prolixus and Triatoma infestans to vertebrate odours on a servosphere. J Comp Physiol A 176: 455-464.

Terakita A 2005. The opsins. Genome Biol 6: 213.

TGSC - Tribolium Genome Sequencing Consortium, Richards S, Gibbs R, Weinstock G, Brown S, Denell R, Beeman R, Bucher G, Friedrich M, Grimmelikhuijzen C, Klingler M, Lorenzen M, Roth S, Schröder R, Tautz D, Zdobnov E, Muzny D, Attaway T, Bell S, Buhay C, Chandrabose M, Chavez D, Clerk-Blankenburg K, Cree A, Dao M, Davis C, Chacko J, Dinh H, Dugan-Rocha S, Fowler G, Garner T, Garnes J, Gnirke A, Hawes A, Hernandez J, Hines S, Holder M, Hume J, Jhangiani S, Joshi V, Khan Z, Jackson L, Kovar C, Kowis A, Lee S, Lewis L, Margolis J, Morgan M, Nazareth L, Nguyen N, Okwuonu G, Parker D, Ruiz S-J, Santibanez J, Savard J, Scherer S, Schneider B, Sodergren E, Vattahil S, Villasana D, White C, Wright R, Park Y, Lord J, Oppert B, Wang L, Liu Y, Worley K, Elsik C, Reese J, Elhaik E, Landan G, Graur D, Arensburger P, Atkinson P, Beidler J, Demuth J, Drury D, Du Y-Z, Fujiwara H 2008. The genome of the model beetle and pest Tribolium castaneum. Nature 452: 949-955.

The International Aphid Genomics Consortium 2010. Genome Sequence of the pea aphid Acyrthosiphon pisum. PLoS Biol 8: e1000313.

Thomas F, Adamo S, Moore J 2005. Parasitic manipulation: where are we and where should we go? Behav Processes 68: 185-199.

Thorne N, Chromey C, Bray S, Amrein H 2004. Taste perception and coding in Drosophila. Curr Biol 14: 1065-1079.

Townson SM, Chang BS, Salcedo E, Chadwell LV, Pierce NE, Britt SG 1998. Honeybee blue and ultraviolet-sensitive opsins: cloning, heterologous expression in Drosophila and physiological characterization. J Neurosci 18: 2412-2422. 
Tracey Jr WD, Wilson RI, Laurent G, Benzer S 2003. painless, a Drosophila gene essential for nociception. Cell 113: 261-273.

Vazquez-Prokopec GM, Ceballos LA, Kitron U, Gürtler RE 2004. Active dispersal of natural populations of Triatoma infestans (Hemiptera: Reduviidae) in rural northwestern Argentina. J Med Entomol 41: 614.

Vinauger C, Buratti L, Lazzari CR 2011a. Learning the way to blood: first evidence of dual olfactory conditioning in a blood-sucking insect, Rhodnius prolixus. I. Appetitive learning. J Exp Biol 214: 3032-3038.

Vinauger C, Buratti L, Lazzari CR 2011b. Learning the way to blood: first evidence of dual olfactory conditioning in a blood-sucking insect, Rhodnius prolixus. II. Aversive learning. J Exp Biol 214: 3039-3045.

Vinauger C, Lallement H, Lazzari CR 2013. Learning and memory in Rhodnius prolixus: habituation and aversive operant conditioning of the proboscis extension response. J Exp Biol 216: 892-900.

Vinauger C, Pereira MH, Lazzari CR 2012. Learned host preference in a Chagas disease vector, Rhodnius prolixus. Acta Trop 122: 24-28.

Vitta AC, Bohman B, Unelius CR, Lorenzo MG 2009. Behavioral and electrophysiological responses of Triatoma brasiliensis males to volatiles produced in the metasternal glands of females. $J$ Chem Ecol 35: 1212-1221.

Vitta AC, Lorenzo MG 2009. Copulation and mate guarding behavior in Triatoma brasiliensis (Hemiptera: Reduviidae). J Med Entomol 46: 789-795.

Vosshall LB, Amrein H, Morozov PS, Rzhetsky A, Axel R 1999. A spatial map of olfactory receptor expression in the Drosophila antenna. Cell 96: 725-736.
Vosshall LB, Hansson BS 2011. A unified nomenclature system for the insect olfactory coreceptor. Chemical Senses 36: 497-498.

Walker RG, Willingham AT, Zuker CS 2000. A Drosophila mechanosensory transduction channel. Science 287: 2229-2234.

Wang G, Qiu Y, Lu T, Kwon H-W, Pitts R, van Loon J, Takken W, Zwiebel LJ 2009. Anopheles gambiae TRPA1 is a heat-activated channel expressed in thermosensitive sensilla of female antennae. Eur J Neurosci 30: 967-974.

Ward J 1981. A comparison of the behavioural responses of the haematophagous bug, Triatoma infestans, to synthetic homologues of two naturally occurring chemicals (n-and iso-butyric acid). Physiol Entomol 6: 325-329.

Xu S, Cang C, Liu X, Peng Y, Ye Y, Zhao Z, Guo A 2006. Thermal nociception in adult Drosophila: behavioral characterization and the role of the painless gene. Genes Brain Behav 5: 602-613.

Xu XZ, Chien F, Butler A, Salkoff L, Montell C 2000. TRPgamma, a Drosophila TRP-related subunit, forms a regulated cation channel with TRPL. Neuron 26: 647-657.

Yamaguchi S, Desplan C, Heisenberg M 2010. Contribution of photoreceptor subtypes to spectral wavelength preference in Drosophila. Proc Natl Acad Sci USA 107: 5634-5639.

Yan Z, Zhang W, He Y, Gorczyca D, Xiang Y, Cheng L, Meltzer S, Jan L, Jan Y 2013. Drosophila NOMPC is a mechanotransduction channel subunit for gentle-touch sensation. Nature 493: 221-225.

Yao CA, Ignell R, Carlson JR 2005. Chemosensory coding by neurons in the coeloconic sensilla of the Drosophila antenna. J Neurosci 25: 8359-8367.

Yin J, Wallach J, Del Vecchio M, Wilder E, Zhou H, Quinn W, Tully T 1994. Induction of a dominant negative CREB transgene specifically blocks long-term memory in Drosophila. Cell 79: 49-58. 